\title{
Effect of dietary n-6 to n-3 polyunsaturated fatty acid ratio on prostaglandin plasma levels and genes expression peroxisome proliferator-activated receptor (PPAR) in pregnant Sprague Dawley rats
}

\author{
Amira Abdulbari Kassem ${ }^{1}$, Md Zuki Abu Bakar ${ }^{1 \star}$, Goh Yong Meng ${ }^{1}$ and Noordin Mohamed \\ Mustapha $^{2}$ \\ 1Department of Veterinary Preclinical Sciences, Faculty of Veterinary Medicine, Universiti Putra Malaysia, 43400 UPM \\ Serdang, Selangor, Malaysia. \\ 2Department of Pathology and Microbiology Veterinary, Faculty of Veterinary Medicine, Universiti Putra Malaysia, 43400 \\ UPM Serdang, Selangor, Malaysia. \\ Accepted 1 July, 2011
}

\begin{abstract}
The peroxisome proliferator-activated receptors (PPARs) are a family of nuclear transcription factors thought to act as receptors for polyunsaturated fatty acids and to reduce production of series 2 prostaglandins (PG). The objective of this study was to investigate the effect of different ratio n-6:n-3 on the PPAR expression of rats endometrial tissue. The findings obtained from this study showed significant induction of PPARס mRNA levels in endomatral cells treatment 1:1 group by 1.38 fold compared with the PPARס mRNA levels in endomatral cells treatment 30:1 group. This induction was due to the cellular demands for prostaglandin were high in the endometrial cells when cells were treated with high ratio n6:n3 on 30:1 group, thus, resulting in an increase in both prostaglandin PGE2 and PGF2 $\alpha$ production by induction of PPAR $\delta$ genes. On the other hand, treatment 1:1 group and control group of endometrial cells did not show any significant changes in mRNA level of PPARס, compared with treatment ratio n6:n3 on 6:1 group and treatment high ratio n6:n3 on 30:1 group of the endometrial cells. These findings show that inhibition of uterine PGF2 $\alpha$ synthesis by n-3 fatty acids may depend on the amount of n- 6 fatty acids reaching the target tissue. In conclusion, PPARס function in the response of rat endometrium to long chain $n-6: n 3$ polyunsaturated fatty acids.
\end{abstract}

Key words: Polyunsaturated fatty acid, gene expression, peroxisome proliferator-activated receptor, prostaglandin, pregnancy rat.

\section{INTRODUCTION}

The PPARs are a family of nuclear receptors activated by some LCFA, eicosanoids and peroxisome proliferators. Three isoforms of PPAR, encoded by separate genes, have been identified date: PPARY, PPAR a and PPARס which upon ligand binding, heterodimerize with the

*Corresponding author. E-mail: zuki.@vet.upm.edu.my Tel: +60-389468333. Fax: +603-89486317.

Abbreviations: PPARs, Peroxisome proliferator-activated receptors; PD, prostaglandins. retinoid receptor and interact with specific PPAR response elements in the promoter region of target genes to affect transcription. Regulation of promoter function is complex, because it is the expression of tissue-specific PPAR and retinoid receptor subtypes, competition for the retinoid receptor binding partner and differences in binding affinity among the PPAR subtypes and among there receptor subtypes (Desvergne and Wahli, 1999).

The PPARs are well known for their roles in lipid metabolism, but they are also involved in development, maturation of the epidermis, the reproduction in several animal models and functions of the nerve, lung, kidney and cardiac tissues (Desvergne and Wahli, 1999; Berger 
and Moller, 2002).

In contrast to PPARa, PPARy has a preference for PUFAs over MUFA or UFA (Khan and Heuvel, 2003). The PPAR $\delta$ are expressed in a wide range of tissues and cells, with relatively higher levels of expression noted in brain, adipose and skin (Huin et al., 2000; Amri et al., 1995). Importantly, in the endometrium PPAR $\delta$ is vital for normal fertility serving as a regulator of $P G$ production and is required for implantation in rodent models (Lim et al., 1997, 1999). MacLaren et al. (2005) reported similar expression of PPAR a and PPARס mRNA levels in BEND cells and endometrium from cyclic and pregnant Holstein cows.

The PPAR $\delta / \alpha$ agonist cPGI had a dramatic stimulatory effect on PGHS-2 mRNA levels and synthesis of PGF2 $\alpha$ and PGE2, which appeared to be mediated at least in part through PPAR $\delta$ (MacLaren et al., 2005). They hypothesized that PPAR $\delta$ is involved in the pregnancy recognition process of cattle and that it mediates at least some of the beneficial effects of long chain omega- 3 PUFA supplementation on fertility. To date, only the PPAR that has been associated with reproductive function is PPAR $\delta$ (Berger et al., 2002). Some fatty acid agonists for PPAR $\delta$ are DEPA, of which the latter may be the most potent activator of this chemical class (Xiao et al., 1998). Studies with mice and rats have shown that PPAR $\delta$ plays a specific role in embryonic development, especially during implantation and decidualization (Ding et al., 2003). Furthermore, a study by Lim et al. (2000) demonstrated that $P G 12$ is the primary $P G$ that is essential for implantation and decidualization and suggested that the effects of PGI2 are mediated by activation of PPAR $\delta$. This suggests that PGs produced by PGHS-2 may exert their effects directly on the nucleus via activation of PPARs. In addition, PGHS-2 deficient mice, decidualization and implantation failures can be reversed by the administration of a PPAR $\delta$-selective agonist (Lim et al., 1997). Collectively, these observations indicate that there may be a role for one or more PPARs in rat's endometrial prostaglandin production. The objective of this study was to characterize PPAR expression activity of rats endometrial tissue in response to known PPAR ligands, as well as to key stimulators and inhibitors of series 2 prostaglandin secretion

\section{MATERIALS AND METHODS}

\section{Animals and diets}

Twenty eight (28) female Sprague-Dawley rats weighing $(240 \pm 20$ $\mathrm{g}$ body weight) were used in this experiment. They were purchased from Veterinary Faculty, Universiti Putra Malaysia. Rats were individually housed in stainless steel cages in a room with a 12/12 $\mathrm{h}$ light/dark cycle at the ambient temperature of 25 to $30^{\circ} \mathrm{C}$. Experiment was carried out according to the guidelines for the use of animals approved by the Animal Care and Use Committee, Faculty of Veterinary Medicine, Universiti Putra Malaysia (UPM/FPV/PS/3.2.1.551/AUP-R23).
After 2 weeks of adaptation, the rats were randomly divided into four treatment groups consisting seven rats in each group. The cod liver oil was used as the main source of $n$-3 PUFA [Eicosapentaenoic acid (EPA) and docosahexaenoic acid (DHA)] and soybean oil is the main source of $n-6$ fatty acids and linolinic acid (LA). The treatment groups include rats fed with normal rat chow diet the control $(\mathrm{C})$, rats fed chow diet supplemented with $5 \%(\mathrm{w} / \mathrm{w})$ SBO and $5 \%(w / w)$ CLO (Diet 1:1), rats fed chow diet added with $8.4 \%(\mathrm{w} / \mathrm{w})$ SBO and $1.6 \%(\mathrm{w} / \mathrm{w})$ CLO(Diet $6: 1)$ and rats fed chow diet added with $9.6 \%(\mathrm{w} / \mathrm{w})$ SBO and $0.4 \%(\mathrm{w} / \mathrm{w})$ CLO (Diet 30:1). The rats were fed $7 \%$ of body weight daily and water was provided ad libitum. The diets were prepared daily to minimize rancidity and oxidative damage, the rats were fed once daily and the left over feeds were collected before new feeding. After 6 weeks of feeding, the stage of estrous cycle of the female rats was determined by vaginal smears taken between 8 to 10 a.m daily (for 2 weeks). Cell types in the smear were subsequently examined microscopically to determine the estrous stage. The consecutive stages of the estrous cycle of cornified cells and the presence of nucleated cells; estrus, presence of only cornified cells; metestrus, presence of leukocytes and fewer cornified cells; and diestrus, mostly polymorphonuclear leukocytes (Turner and Bagnara, 1976). Vaginal smears of 28 female rats were performed every morning during for 2 weeks and unstained native material was observed using the microscope without the aid of the condenser lens. Using the $10 \times$ objective lens, it was easier to analyze the proportion among the three cellular types, which were present in the vaginal smear. While using the $40 \times$ objective lens, it was easier to recognize each one of these cellular types Mating was done during proestrus stage by placing one adult male and one female into individual cages for $24 \mathrm{~h}$. The presence of spermatozoa in the vaginal the following morning via vaginal smear was defined as day 0 of pregnancy. Pregnant females were separated from male rats on the day of pregnancy. The rat were individually housed in polycarbonate cages $(43 \times 28 \times$ $16 \mathrm{~cm})$ with sawdust bedding, in controlled room temperature $(23 \pm$ $2^{\circ} \mathrm{C}$ ) with $12 \mathrm{~h}$ of light and $12 \mathrm{~h}$ of darkness. On the day 14 prior to sacrifice, food was withdrawn at 9:00 a.m. and the animals were sacrificed at 9:00 a.m the following morning on the day 15 of pregnancy after 10 weeks ( 8 weeks +15 days) of feeding rats were anesthetized with an intraperitoneal injection of $60 \mathrm{mg} / \mathrm{kg}$ body weight ketamine $+8 \mathrm{mg} / \mathrm{kg}$ body weight xylazine and blood samples were obtained by cardiac puncture for determining plasma Fatty acids profile and prostaglandin concentrations (PGE2 and PGF2 $\alpha$ ). Total RNA was isolated from fresh frozen uterus tissues kept in liquid nitrogen, by RiboPureTM RNA Isolation Kit according to the manufacturer's instructions (Ambion, Austin, Texas, USA).

\section{RNA extraction}

Figure 1 shows the total RNA was isolated from uterus tissues using the RiboPure RNA isolation kit according to the manufacturer's instructions. The purity of the extracted RNA was determined by measuring the ratio of the optical density at 260 and $280 \mathrm{~nm}$ using a spectrophotometer (BioRad, USA). The total RNA concentration was determined by measuring the absorbance at 260 $\mathrm{nm}$. The integrity and size distribution of the total RNA was determined by using a 1.5 agarose gel. The $18 \mathrm{~S}$ and $28 \mathrm{~S}$ RNA bands were visualized under UV light using gel image instrumentation.

\section{Quantitative real time PCR}

SYBR green primers specific for PPARס and beta actin genes were designed and synthesized by (Oligo- Singapore) and supplied by Next Gene Scientifc Sdn. Bhd. from the gene sequence of rat 


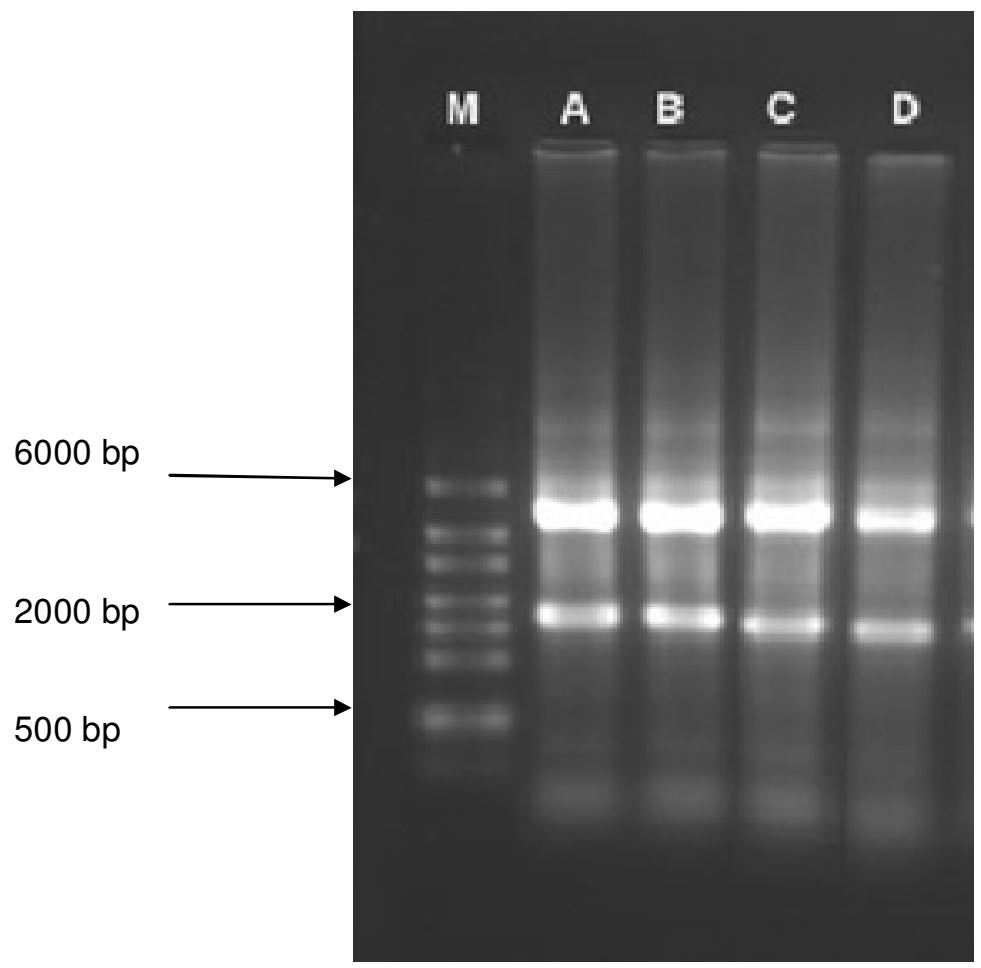

Figure 1. RNA extracted from uterine tissue. Lane $M=$ marker, lane $A=$ Diet 1:1, lanes $B=$ Diet 6:1, lane $C=$ Diet 3:1, lane $D=$ Diet control.

Table 1. SYBR green specific primers used in this study.

\begin{tabular}{llc}
\hline Gene & Sequence & Product size (bp) \\
\hline PPAR $\delta \mathrm{F}$ & CAGCTGCCTTGGTGTAACCAT & \multirow{2}{*}{126} \\
PPAR $\delta \mathrm{R}$ & CCTGCTCACAGACCATCAATTCTAG & \\
Beta actin $\mathrm{F}$ & CCAACTGGGACGACATGGAG & 144 \\
Beta-actin R & TCAAACATGATCTGGGTCATCTTC & \\
\hline
\end{tabular}

$\mathrm{F}=$ Forward, $\mathrm{R}=$ reverse and $\mathrm{bp}=$ base pair.

(rattus norvegicus) adopted from the NCBI (National Center for Biotechnology Information) GenBank Database (www.ncbi.nlm. nih.gov). GenBank accession number code for PPAR $\delta$ is NM_013141.2 and beta actin gene is NM_031144 (Table 1).

Real-time quantitative PCR was performed using the quintet probe real time PCR master mix (QIAGENE, USA) according to the manufacturer's instructions. Concentration of the forward, reverse primers and RNA template, as well as the annealing temperature was optimized using real time PCR. The real-time quantitative PCR reaction for each sample was carried out in triplicate. Briefly, a reaction volume of $50 \mu \mathrm{l}$ containing $25 \mu \mathrm{l}$ master mix, $2 \mu \mathrm{l}$ of $200 \mathrm{nM}$ each forward and reverse primers, $1 \mu \mathrm{l}$ for the SYBR Green, $17 \mu \mathrm{l}$ $\mathrm{dH}_{2} \mathrm{O}$ and $4 \mu \mathrm{l}$ of the template RNA at concentration of $100 \mathrm{ng} / \mu \mathrm{l}$. Real-time PCR amplification of RNA was carried out for 40 cycles with the gain set at 2.33. After an initial incubation for $15 \mathrm{~min}$ at $95^{\circ} \mathrm{C}$ PCR cycle comprised denaturation for $30 \mathrm{~s}$ at $50^{\circ} \mathrm{C}$, annealing for $5 \mathrm{~s}$ at $72^{\circ} \mathrm{C}$, analysis of the gene expression data was performed using a $\triangle \Delta C T$ method of relative quantification, according to a previous report by Kenneth et al. (2001). RotorGene analysis software (version 6.0) was used to analyze all the results from the PCR assays.

\section{Statistical analysis}

Data were analyzed as a completely randomized design experiment using the general linear model of SAS 9.02 software (Statistical Analysis Systems Institute Inc., 1992). The gene expression (PPAR $\delta)$ of the rat treatment diets were analyzed across treatment groups using the one-way analysis of variance (ANOVA) method. Significantly different means were then elucidated using the Duncan's.

\section{RESULTS}

Treatment of supplementation high level soybean oil on treatment Diet 30:1 for 2 month feeding increased levels of PPAR $\delta$ of mRNA by 8.82 fold, respectively. Supplementation high ratio n6:n3 on Diet 30:1 compared with low ratio $n 6: n 3$ on Diet 1:1 (1.38) (Table 2), results in an increase in the control (Diet 4) PPAR $\delta$ mRNA 
Table 2. The effect of $n 6: n 3$ on the expression level of PPRA $\delta$ gene in the endomatrim tissue $(n=7)$.

\begin{tabular}{lccccc}
\hline Group & Average $\mathbf{C}_{\boldsymbol{T}}$ of PPRA $\boldsymbol{\delta}$ & Average $\mathbf{C}_{\boldsymbol{T}}$ of beta actin & $\boldsymbol{\Delta} \mathbf{C}_{\boldsymbol{T}}$ & $\boldsymbol{\Delta} \boldsymbol{\Delta} \mathbf{C}_{\boldsymbol{T}}$ & $\mathbf{2}^{-\Delta \Delta C T}$ (fold) \\
\hline Diet 1:1 & $26.60 \pm 0.04$ & $18.96 \pm 0.70$ & 7.64 & -0.46 & 1.38 \\
Diet 6:1 & $25.26 \pm 0.28$ & $18.35 \pm 0.56$ & 6.91 & -1.19 & 2.28 \\
Diet 30:1 & $21.58 \pm 0.15$ & $16.62 \pm 0.24$ & 4.96 & -3.14 & 8.82 \\
Diet Control & $27.47 \pm 0.84$ & $19.37 \pm 0.75$ & 8.10 & 0.01 & 1.00 \\
\hline
\end{tabular}

$\Delta \mathrm{C}_{\mathrm{T}}=\mathrm{C}_{\mathrm{T}}$ PPRA $\delta-\mathrm{C}_{\mathrm{T}}$ of beta actin, $\Delta \Delta \mathrm{C}_{\mathrm{T}}=\Delta \mathrm{C}_{\mathrm{T}}$ treated cells $-\Delta \mathrm{C}_{\mathrm{T}}$ control.

Table 3. The plasma PGF2 $\alpha$ and PGE2 concentrations $(\mathrm{ng} / \mathrm{ml})$ at 15 days of pregnancy $(n=7)$.

\begin{tabular}{lcc}
\hline Treatment & PGF2 $\alpha(\mathbf{n g} / \mathbf{m l})$ & PGE2 $(\mathbf{n g} / \mathbf{m l})$ \\
\hline Diet 1:1 & $469.33 \pm 48.08^{\mathrm{C}}$ & $700.94 \pm 25.34^{\mathrm{c}}$ \\
Diet 6:1 & $764.49 \pm 41.91^{\mathrm{b}}$ & $1124.82 \pm 67.08^{\mathrm{b}}$ \\
Diet 30:1 & $1110.56 \pm 106.23^{\mathrm{a}}$ & $1971.76 \pm 96.73^{\mathrm{a}}$ \\
Diet control & $576.51 \pm 22.37^{\mathrm{C}}$ & $611.85 \pm 16.98^{\mathrm{C}}$ \\
\hline
\end{tabular}

Values with different superscripts within column differ significantly at $\mathrm{P}<0.05$.

expression from $1.00 \pm 0.01$ to $8.82 \pm 1.84$ in Diet $30: 1$. In the Diet 6:1 group, the PPAR $\delta$ expression level was increased significantly by 2.28 fold when compared with the Diet control group. While the PPARס mRNA expression levels was significantly highest in Diet 30:1 group when compared with Diet $1: 1$ and 6:1 groups, where the level was 8.82 fold higher than the Diet control group.

For both PGF2 $\alpha$ and PGE2, the levels were significantly higher $(P<0.05)$ in Diet $30: 1$ group when compared with other groups. There were significant difference $(P>0.05)$ in PGF2 $\alpha$ concentrations between the groups fed with diet Diet 1: 1, 6:1 and 30:1 in which it was higher in Diet 30:1, followed by Diet $6: 1$ and least in Diet $1: 1$ groups. By increasing the plasma arachidonic acid (AA) in Diet 30:1, the production of PGF2 $\alpha$ and PGE2 increased significantly when compared with other groups. Amira et al; 2010 (Table 3).

\section{DISCUSSION}

The peroxisome proliferator activated receptors (PPARs) are a family of nuclear transcription factors and are thought to act as receptors for polyunsaturated fatty acids and to reduce production of series 2 prostaglandins (PG). The evidence is rapidly accumulating that fatty acids may have additional serious major effects on the synthesis of eicosanoid in domestic animals (Baguma-Nibasheka et al., 1999; Mattos et al., 2003). Depending on the amount and type of specific fatty acids to achieve the target tissues, fatty acids can either stimulate (Burke et al., 1996; Filley et al., 1999) or inhibit (Baguma-Nibasheka et al., 1999; Mattos et al., 2003; Cheng et al., 2001) the synthesis of prostanoid. The AA that is released by phospholipid hydrolysis is acted upon by PGHS-2 to form $\mathrm{PGH} 2$, which then is converted to PGF2a. Consistent with a previous observation (Mattos et al., 2003), this study provided evidence for $\mathrm{AL}(n-6)$ regulation of PGHS2 mRNA abundance in endometrium cell. As discussed earlier, supplementation of linoleic acid $(n-6)$ may induce endometrial PGF2 $\alpha$ production through competitive displacement of $A A$ from membrane phospholipids and/or through alteration of the PGHS-2 enzymatic activity.

The polyunsaturated fatty acids get several physiological changes in the alteration of the activity or the synthesis of nuclear PPARs (Bocher et al., 2002). In mice, PPARס deficiency leads to placental defects and frequent mid gestational results lethality (Barak et al., 2002), suggesting that this nuclear receptor may play an important role in controlling reproductive processes in mammals. Consistent with in vivo experiment (CaldariTorres et al., 2006), supplementation of the EPA had no detectable effects on PPARס response to PDBu in cultured BEND cells. The results suggest that supplementation of the $n-3$ fatty acids may alter endometrial PGF2 $\alpha$ production through a mechanism which does not require the induction of PPARס gene. However, whether and how these fatty acids may control the activity of this nuclear receptor guarantees further investigation and this nuclear receptor may play an important role in the control of reproductive processes in mammalian species.

In this study, the molecular mechanisms by which ratio of $n 6: n 3$ fatty acids regulated key genes that are involved in prostaglandin production on endometrial cells were investigated. Quantitative real time PCR analysis was performed to quantify the expression level of the mRNA of all the genes. For the RNA purity, the $A_{260}: A_{280}$ ratios of 1.8:2.0 were typically obtained. Thus, the purity less than 1.8 was not accepted for further experiment. In addition, 
the two bands of RNA (28S and $18 \mathrm{~S}$ ) are clearly visible as shown in Figure 1. The $28 \mathrm{~S}$ band showed intensity double that of the $18 \mathrm{~S}$ band which indicate good quality of extracted RNA. It was reported that the successes in the expression analysis depends on the quality of RNA (Duggan et al., 1999).

The findings obtained in this study showed significant induction of PPARס mRNA levels in the endometrial cells of treatment Diet $1: 1$ by 1.38 fold as compared to the PPAR $\delta$ mRNA levels in the endometrial cells of treatment Diet $30: 1$ by 8.82 groups. This induction due to the cellular demands for prostaglandin were high in the endometrial cells when cells were treated with high ratio of $n 6: n 3$ in Diet 30:1 group, thus, resulting in an increase in both prostaglandin PGE2 and PGF2 $\alpha$ production by induction of PPARס genes (Achard et al., 1997). On the other hand, treatment Diet $1: 1$ and control Diet control of endometrial cells did not show any significant changes in mRNA level of PPARס when compared with the medium ratio of $n 6: n 3$ in Diet $6: 1$ and high ratio of $n 6: n 3$ in Diet 30:1 of the endometrial cells. These findings which are consistent with previous studies showed that inhibition of uterine PGF2 $\alpha$ synthesis by $n-3$ fatty acids may depend on the amount of $n-6$ fatty acids reaching the target tissue. Increasing concentrations of LA in the cell culture system may increase the availability of $A A$ in membrane phospholipids and therefore, decrease the competition by $n-3$ fatty acids for the PGHS-2 enzyme (Trujillo and Broughton, 1995; Achard et al., 1997).

In this study, we showed that PPARס is a likely mediator of some of the effects of long chain n- 6 PUFA action in the pregnant rat endometrium. The relative level of PPAR $\delta$ mRNA expression in rat endometrial cells is under the influence of different ratio of $n 6: n 3$ to initiate pulsatile release of PGF2 $\alpha$ and consequently, luteolysis (MacLaren et al., 2003; MacLaren et al., 2006). Ding et al. (2003) showed that PPAR $\delta$ mRNA regulated in uterine epithelium in early pregnancy of rodent and is induced in uterine subluminal stroma by the presence of the blastocyst

\section{Conclusion}

Fatty acid stimulated PGF2 $\alpha$ production and up-regulated PPAR $\delta$ gene expression in pregnant rat. These findings indicate that the net inhibition of uterine endometrial PGF2 $\alpha$ synthesis by $n-3$ fatty acids may depend on the availability of $n-6$ fatty acids within the target tissue.

\section{REFERENCES}

Achard F, Gilbert M, Bénistant C, Ben Slama S, DeWitt DL, Smith WL, Lagarde M (1997). Eicosapentaenoic and docosahexaenoic acids reduce PGH synthase 1 expression in bovine aortic endothelial cells. Biochem. Biophysic. Res. Commun. 241(2): 513-518.

Amri EZ, Bonino F, Ailhaud G, Abumrad NA, Grimaldi PA (1995).
Cloning of a protein that mediates transcriptional effects of fatty acids in preadipocytes. Homology to peroxisome proliferator-activated receptors. J. Biol. Chem. 270(5): 2367-2371.

Amira A. B. K, A. B. Z Zuki, Y. M Goh, M. M Noordin and M. Ebrahimi. (2010). Effects of varying levels of $n-6: n-3$ fatty acid ratio on plasma fatty acid composition and prostanoid synthesis in pregnant rats Afr. J. Biotechnol Vol. 9 (51), pp. 8881-8888.

Baguma-Nibasheka M, Brenna JT, Nathanielsz PW (1999). Delay of Preterm Delivery in Sheep by Omega-3 Long-Chain Polyunsaturates. Bio. Rep. 60(3): 698-701.

Barak Y, Liao D, He W, Ong ES, Nelson MC, Olefsky JM, Boland R (2002). Effects of peroxisome proliferator-activated receptor $\delta$ on placentation, adiposity, and colorectal cancer. Proceedings of the National Aca. Sci. United States of Amer. 99(1): 303 -308.

Berger J, Moller DE (2002). The mechanisms of action of PPARs. Ann. Rev. Med. (53): 409-435.

Bocher V, Pineda-Torra I, Fruchart J, Staels B (2002). PPARs: transcription factors controlling lipid and lipoprotein metabolism. Ann. New York Acad. Sci. (967): 7-18.

Burke JM, Carroll DJ, Rowe KE, Thatcher WW, Stormshak F (1996). Intravascular infusion of lipid into ewes stimulates production of progesterone and prostaglandin. Biol. Rep. 55(1): 169-175.

Caldari-Torres C, Rodriguez-Sallaberry C, Greene E, Badinga L (2006). Differential Effects of $n-3$ and $n-6$ Fatty Acids on Prostaglandin F2[alpha] Production by Bovine Endometrial Cells. J. Sci. 89(3): 971977.

Cheng Z, Robinson R, Pushpakumara P, Mansbridge R, Wathes D (2001a). Effect of dietary polyunsaturated fatty acids on uterine prostaglandin synthesis in the cow. J. Endocrinol. 171(3): 463-473.

Desvergne B, Wahli W (1999). Peroxisome proliferator-activated receptors: nuclear control of metabolism. Endocrine Rev. 20(5): 649688.

Ding NZ, Teng CB, Ma H, Ni H, Ma XH, Xu LB, Yang ZM (2003). Peroxisome proliferator-activated receptor $\delta$ expression and regulation in mouse uterus during embryo implantation and decidualization. Mol. Reprod. Dev. 66: 218- 224.

Duggan DJ, Bittner M, Chen Y, Meltzer P, Trent JM (1999). Expression profiling using cDNA microarrays. J. Nature Genet Supplement 21: 10-14.

Filley S, Turner H, Stormshak F (1999). Prostaglandin F2a Concentrations, Fatty Acid Profiles, and Fertility in Lipid-Infused Postpartum Beef Heifers. Bio. Reprod. 61(5): 1317-1323.

Huin C, Corriveau L, Bianchi A, Keller JM, Collet P, Krémarik-Bouillaud P, Domenjoud L, Bécuwe P, Schohn H, Ménard D, Dauça M (2000). Differential expression of peroxisome proliferator-activated receptors (PPARs) in the developing human fetal digestive tract. The J.Histochem. Cytochem.: Official J. the Histochem. Society, 48(5): 603-611.

Khan SA, Vanden Heuvel JP (2003). Role of nuclear receptors in the regulation of gene expression by dietary fatty acids (review). J. Nutr. Biochem. 14(10): 554-567.

Lim GP, Calon F, Morihara T, Yang F, Teter B, Ubeda O, Salem N (2005). A Diet Enriched with the Omega-3 Fatty Acid Docosahexaenoic Acid Reduces Amyloid Burden in an Aged Alzheimer Mouse Model. J. Neurosci. 25(12): 3032-3040.

Lim H, Dey SK (2000). PPAR[delta] Functions as a Prostacyclin Receptor in Blastocyst Implantation. Trends in Endocrinol. Metabol. 11(4): 137-142.

Lim H, Gupta RA, Ma W, Paria BC, Moller D E, Morrow JD, DuBois RN (1999). Cyclo-oxygenase-2-derived prostacyclin mediates embryo implantation in the mouse via PPARס. Genes Dev. 13(12): 15611574.

Lim H, Paria BC, Das SK, Dinchuk JE, Langenbach R, Trzaskos JM, Dey SK (1997). Multiple female reproductive failures in cyclooxygenase 2-deficient mice. Cell, 91(2): 197-208.

MacLaren LA, Guzeloglu A, Michel F, Thatcher WW (2006) Peroxisome proliferator-activated receptor (PPAR) expression in cultured bovine endometrial cells and response to omega-3 fatty acid, growth hormone and agonist stimulation in relation to series 2 prostaglandin production. Domestic Anim. Endocrinol. 30(3): 155-169.

Mattos R, Guzeloglu A, Badinga L, Staples CR, Thatcher WW (2003a). Polyunsaturated fatty acids and bovine interferon-tau modify phorbol 
ester-induced secretion of prostaglandin F2 alpha and expression of prostaglandin endoperoxide synthase- 2 and phospholipase-A2 in bovine endometrial cells. Biol. Reprod. 69(3): 780-78.

Trujillo EP, Broughton KS (1995). Ingestion of $n-3$ polyunsaturated fatty acids and ovulation in rats. J. Reprod. Fertil. 105(2): 197-203.
Xiao CW, Liu JM, Sirois J, Goff AK (1998). Regulation of cyclooxygenase-2 and prostaglandin $F$ synthase gene expression by steroid hormones and interferon-tau in bovine endometrial cells. Endocrinology, 139(5): 2293-2299. 